\title{
MINIMAL RESIDUAL DISEASE IN EARLY COLORECTAL CARCINOMA
}

\author{
A. Petrov ${ }^{1 *}$, M. Gulubova ${ }^{2}$, T. Vlaykova ${ }^{3}$, G. Minkov ${ }^{1}$, Y. Yovchev ${ }^{1}$ \\ ${ }^{1}$ Department of Surgery, Faculty of Medicine, Trakia University, Stara Zagora, Bulgaria \\ ${ }^{2}$ Department of Pathology, Faculty of Medicine, Trakia University, Stara Zagora, Bulgaria \\ ${ }^{3}$ Department of Chemistry and Biochemistry, Faculty of Medicine, Trakia University, Stara Zagora, \\ Bulgaria
}

\begin{abstract}
Introduction: The detection and importance of cancer cells circulating in blood is a subject to discussion for more than a century. Their prognostic value for patients with colorectal cancer is still disputable.

Aim: The present study provides information about the specificity and sensitivity of molecular biology, oncogenetics and histopathological methods for early diagnostics of minimal residual disease in the blood of colorectal cancer patients.

Scope: PUBMED query results from 1975 to 2011 were analyzed. The information provides evidence that the presence of such cells is essential for monitoring the progression and therapeutic response of this oncological disease.

Conclusions: During the last decade, new technologies have allowed to use methods with substantial sensitivity and specificity for detection of minimal residual disease in oncological patients, including those with colorectal carcinoma. Data have shown that these cells were with considerable metastatic potential and that their eradication had a direct effect on patients' survival. Therefore, the improvement of methods for early diagnostics and the subsequent specific characterization of initial tumour levels have caused a revision of concepts for operative and conservative treatment of oncological patients. Their further research would give new possibilities for individual assessment of the risk for metastasis, different from the standardized and commonly accepted TNM staging.
\end{abstract}

Key words: colorectal cancer, circulating tumour cells, residual disease, survival, prognosis.

\section{INTRODUCTION}

The spread of malignant tumours occurs mainly via lymph and blood vessels, resulting in metastases in regional lymph nodes and internal organs. Lymphatic spread is characteristic for most neoplasms in humans, but carcinoma metastases in lymph nodes are not always fatal. In some cancer types however, the existing lymphatic spread is a prognostic factor that influences the therapy and the prognosis of disease. On the other hand, haematogenous spread of solid carcinomas is the greatest clinical challenge in oncology and is essential for the outcome of the disease.

\footnotetext{
*Correspondence to: Dr Alen Petrov, MD, Bulgaria , Stara Zagora 6000, University Hospital

"Prof. Stoian Kirkovich", Department of Surgical

Disease, Fax 35942600 705, E-mail:

dr.delon81@gmail.com
}

On a global scale, the treatment of colorectal cancer patients remains a challenge from a diagnostic and therapeutic point of view. Among neoplasms, it is the third commonest cause of death in males after prostate and lung cancer $(10.0 \%)$, while second in females after breast cancer $(9.4 \%)$. According to Parkin et al. colorectal cancer is 2.4 times more frequent than rectal cancer (1).

In 2008, newly registered patients with this disease are 1,235,108 (663,904 men and 571,204 women). The death rate for the same year attains 609,051 (men - 320,397; women - 288,654). In Bulgaria, new cases for 2008 are 4,625 or $0.38 \%$ ) (men $-2,591$ or $0.39 \%$; women $-2,034$ or $0.35 \%$, and fatal outcomes are 2,541 or $0.42 \%$ (2). 
PETROV A., et al.

Despite that, the total mortality rate related to this disease has considerably decreased during the last decades, the five-year survival rate continues to range between $80-90 \%$ for patients in clinical stage I, decreased to $70-75 \%$ in those in stage II. Survivors in stage III are only 50$35 \%$. Data about stage IV are even more discouraging, as only $7 \%$ of patients remain alive beyond the fifth year $(3,4,5)$.

According to data reported by August DA et al. 1984, Ghossein RA et al. 2000, and Tebbutt NC et al. 2002, $80 \%$ of patients undergo a radical treatment during the first surgery but subsequently, 30 to $50 \%$ experience remote metastatic disease. The reason is the presence of residual cancer cells in blood and other organs, which at a later stage cause further progression of the disease $(6,7,8)$.

The precise diagnosis of malignancy is essential for scheduling a proper therapy. The modern development of biomedical technologies allows detecting tumour cells at a molecular level. An important and unsolved issue is whether molecular staging is accurate enough for prognostication of a given oncology patient.

Metastases are responsible for the major part of oncological death rate and it could be therefore assumed that the detection of metastatic cells should entail a decision for aggressive therapy. The prognostic value of the different tumour cells in blood or lymph nodes (circulating tumour cells, CTC) is recently questioned. Decisions about the type of treatment in metastatic colorectal cancer are more difficult to make due to the increased likelihood to detect such cells in peripheral blood or bone marrow at the background of conflicting data about their prognostic value for patient's outcome (9).

According to Keene SA et al. 2001, the prognostic value of detected circulating cells is yet uncertain, necessitating a more extensive investigation in the problem (10).

Braun S et al. 2005 reviewed a number of strategies after the discovery of single metastatic cells in bone marrow or blood. They discussed the techniques and the probability for detection of micrometastases as precursors of a future recurrence. As an important contribution, they reviewed the attempts for geno- and phenotyping of these cells, important for monitoring of processes in adjuvant and metastatic conditions (11).

The fast development of cytology, immunohistochemistry and molecular biology has largely provided an insight to oncological disease progression. The terms minimal residual disease and minimal tumour load were introduced in clinical practice.

There is not a clear definition or standard terminology with respect to micrometastasis. Synonyms used are isolated tumour cells, disseminated tumour cells, occult metastatic cells and micrometastatic cells. In a general sense, micrometastasis is regarded a persisting malignant cell population that is not eradicated with therapy and that has remained under the sensitivity threshold of existing conventional diagnostic techniques.

Initially, micrometastases were defined as tumour cell depots that could be detected only by light microscopy. In the view of Haermanek P et al. 1999, isolated tumour cells should be distinguished from micrometastases on the basis of contact with vascular or lymph sinus wall, extravasation, extravascular stromal reaction and tumour cell proliferation (12).

At present, minimal residual disease is considered as precursor of micrometastasis and is regarded as the clinical condition, in which tumour cells are detected in patient's blood or bone marrow by contemporary diagnostic techniques, but without clinical signs of disease (13). Its importance for cancer further progression will be investigated from now on.

While the importance of minimal residual disease for breast cancer patients was partly established by Sharp JG /1992/ (14) and Stadmauer EA /1999/ (15), the issue with tumour cells detected in the blood of colorectal and rectal cancer patients is different $(16,17)$.

The detection of tumour cells in peripheral blood predetermines the real behaviour of the tumour (18), and their detection prior to the clinical disease makes them a factor for consequent recurrence or metastases $(19,20)$, related to change in the cytostatic drug treatment protocols and duration $(6,7,8)$.

Clinically, numerous tumour cells could be detected in the blood of cancer patient and at the 
same time, a very small proportion of them could give rise to metastases (21).

In the view of Kerr et al., $20 \%$ of patients with early colorectal cancer exhibit lymph node metastases (22), which predetermine the fatal outcome in $90 \%$ of cases (23). In an earlier report of Liefers GJ et al. (1998), the failure of some of used cytostatic treatment protocols was shown to be due to detected lymph node micrometastases (24).

Thus, factors linked to local spread, histological features and lymph nodes metastases remained clinically important for survival $(25,26,27)$.

The authors concluded that the presence of these cells in peripheral blood did not correlate to lower survival rates in patients with early breast cancer, while Karina Kl, /1998/ showed that after experimental implantation of tumour cells in blood, despite the substantial initial concentration, the final result was also lack of metastases $(28,29,30)$.

Of particular importance is whether the metastatic potential of detected circulating tumour cells is high or low. To confirm these hypotheses, the following techniques were developed and implemented during the recent years: in vivo videomicroscopy, ELISA, immunological methods, PCR or RT-PCR and CellSearch system (31).

Further investigations have shown that treatment failures were partly due to CTC in blood or in peritoneal fluid and bone marrow $(24,32,33)$. Parallelly, it was established that these cells reduced the five-year survival rate of colorectal cancer patients in the second clinical stage from $75 \%$ in the group of patients negative for minimal residual disease to $36 \%$ in the CTCpositive group (24).

Therefore, the development of new methods allowing for early diagnostics and eradication of detected tumour cells in blood would substantially slow down the relapse and would increase the five-year survival rate (34).

To support these hypotheses, numerous publications have been devoted to the problem during the last years, each of them reporting a method for diagnostics of blood tumour cells in oncology patients (35).
PETROV A., et al. METHODS FOR DIAGNOSTICS OF TUMOUR CELLS IN THE BLOOD OF ONCOLOGY PATIENTS

Today, these diagnostic methods could be conditionally assigned to one of the following groups (8):

1. Conventional cytology (cytological and histopathological);

2. In vivo videomicroscopy;

3. Immunological assays - ELISA, flow cytometry etc.

4. Molecular biology techniques: polymerase chain reaction (PCR) and reverse transcription PCR (RT-PCR).

5. The CellSearch system.

\section{Conventional cytology}

During the past century, the detection of tumour cells in blood depended upon the cytological examination of routinely stained blood smears. Tumour cells' detection rate by routine cytological and histopathological methods remains with a low diagnostic value up to $4 \%$ of cases $(36,37)$.

It was then established that the incidence of false positive results attained $67 \%$ due to the nonspecific staining of mononuclear lymphocytes (38, 39, 40). During the last two decades however, a number of new techniques were developed and numerous studies have been carried out permitting the specific detection and characterization of circulating tumour cells in breast and colorectal cancer patients. In general, patients with tumour cells in the blood have a poorer prognosis compared to those without such cells $(11,41,42,43)$.

Nevertheless, the identification of circulating tumour cells could be problematic due to the different sensitivity and specificity of these methods. For example, single necrotic cells shed from the primary tumour during the surgery, could be detected in peripheral blood, but they are not viable and therefore, their presence is not indicative for the further disease progression. On the contrary, the detection of multiple cells could be more relevant to the outcome as these cells are probably indicating an earlier stage of haematogenous spread. The issues with the blood cell counts needed for analyses are still not clear (44). 
PETROV A., et al.

\section{In vivo videomicroscopy}

In vivo videomicroscopy method is based on a relatively simple and fast procedure for clear CTC identification. It includes intravenous infection of a tumour-specific fluorescent ligand, followed by imaging of superficial blood vessels by multiphoton fluorescence. By this technique, about $2 \mathrm{CTC} / \mathrm{ml}$ blood could be identified. The non-invasive imaging of peripheral blood tumour cells could improve the sensitivity of detection permitting analysis of a relatively larger blood volume (virtually the entire patient's blood volume) but so far, these analyses have been proved efficient only when tumour cells were marked ex vivo, prior to intravenous injection (45).

The method is promising for screening, early detection of disease progression and evaluation of therapeutic response for numerous cancers. It could easily detect less than one circulating epithelial cells per ml blood (46). The in vivo microscopy reveals the role of tumour cells during both primary and metastatic tumour growth $(45,47)$.

A disadvantage of the method is the need for a specific marker to visualize circulating tumour cells.

\section{Immunological methods}

ELISA (enzyme-linked immunosorbent assay) ELISA was firstly used in 1971. Later, telomerase was used as a more precise marker for early diagnostics of tumour cells in the blood of colorectal cancer patients (Table 1) (48). The implementation of immunomagnetic separation increased the sensitivity of the method. Nanoparticles coated with BerEP4 (Figure 1) are used, and the sensitivity attained 1 tumour cells per 1 million epithelial cells (49). Nevertheless, the issues with finding and applying serum markers to detect such cells in blood are not solved, thus making the technique less appropriate.

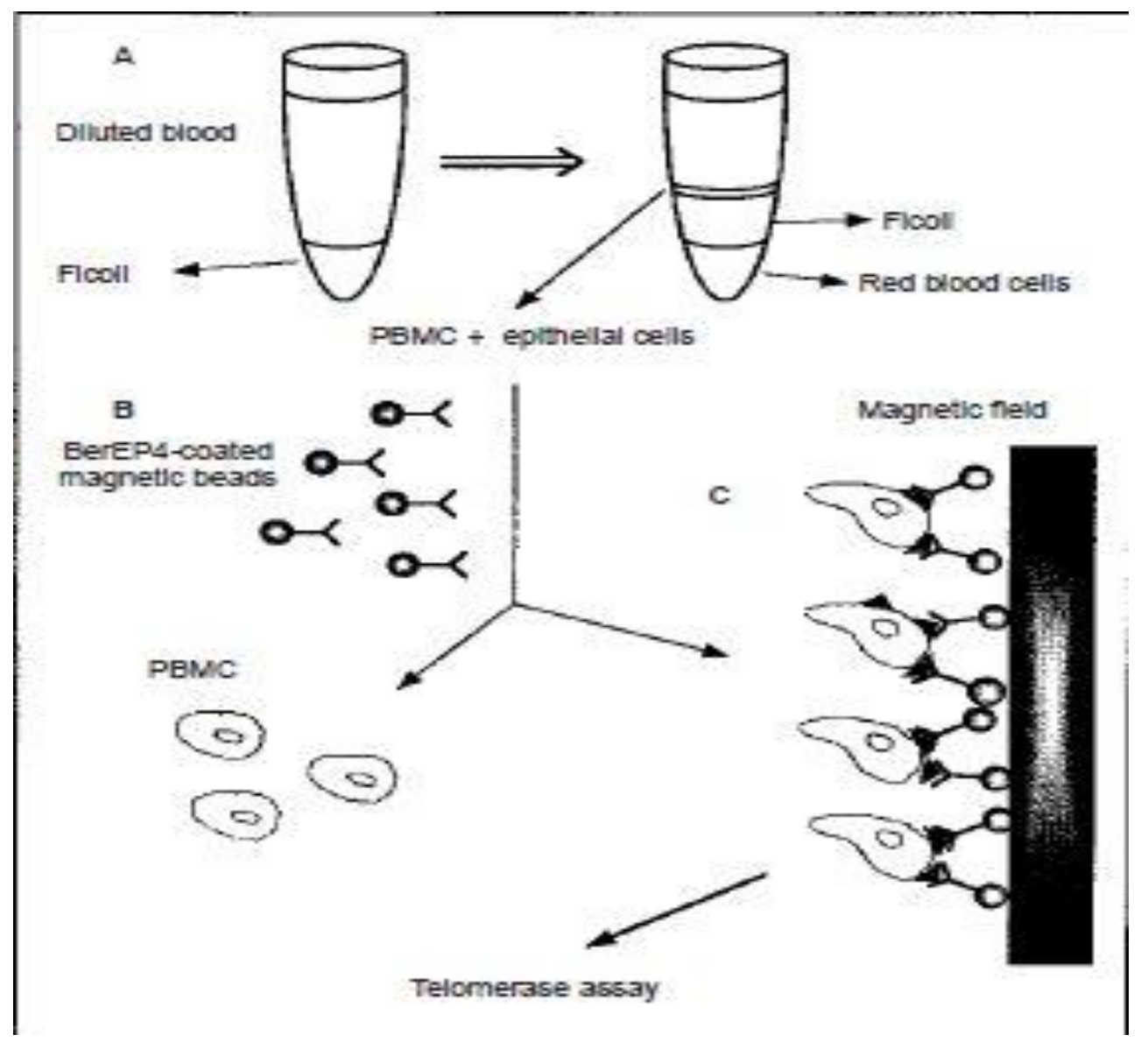

Figure 1. Schematic representation of the method for detection of telomerase activity of CTC, using immunomagnetic separation with BerEP4 (Koelink et al, BMC Cancer 2009; 9:88) (49) 
Table 1. Sensitivity and specificity of ELISA

\begin{tabular}{|l|l|l|c|c|c|}
\hline Year & Author & Method & $\begin{array}{l}\text { Number of } \\
\text { patients }\end{array}$ & Sensitivity & Specificity \\
\hline $2001 \Gamma$. & Gauthier LR & $\begin{array}{l}\text { Telomerase } \\
\text { activity }\end{array}$ & 11 & $72 \%$ & $\mathrm{P}>0.0001$ \\
\hline 2009 & $\underline{\text { Koelink PJ }}$ & CK18-Asp396 & 49 & $95 \%$ & $\mathrm{P} \leq 0.05$ \\
\cline { 3 - 6 } & total CK18 & & \\
\hline
\end{tabular}

\section{Immunocytological and immunohistochemical methods}

By the end of 1980, the analysis of circulating tumour cells by immunohistochemistry was introduced. Specific antibodies are used for detection and selection. Immunological methods are used for high-sensitivity detection of micrometastases in bone marrow, lymph nodes and peripheral blood $(32,50,51,52)$.

The concentration of tumour cells in bone marrow aspirate or blood is done by centrifugation of the aspirate in separation medium resulting in CTC migration in the mononuclear cell layer. They are used for cytological smears or slides that are further processed with monoclonal or polyclonal antibodies recognizing a specific epithelial antigen, which are then identified by immunocytochemical or immunofluorescence methods (Figures 2, 3 and 4).

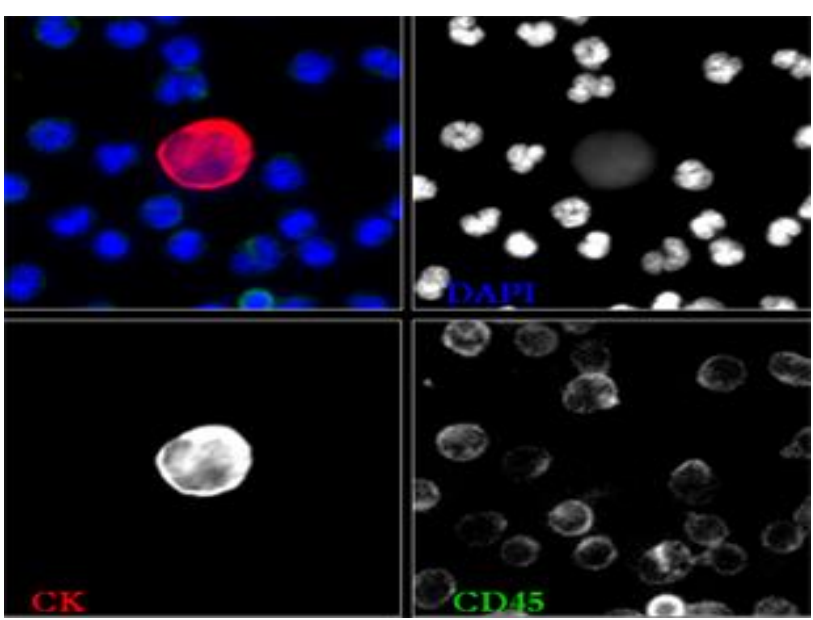

Figure 2. Identification of tumour cells by fluorescence microscopy (Fehm et al, Clin Cancer Res. 2002; 8(7):2073-84)
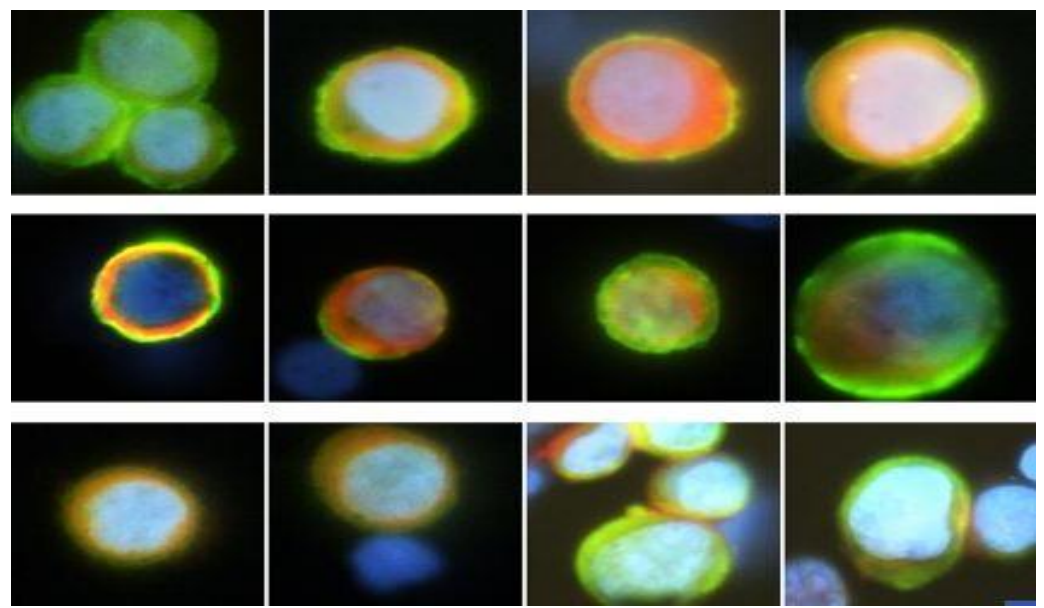

Figure 3. Circulating tumour cells isolated by Lymphoprep from the peripheral blood of colorectal cancer patients (Ntouroupi et al., British Journal of Cancer 2008; 99: 789-795 ) 
PETROV A., et al.

The disadvantages of the method are related to the risk of false positive results due to nonspecific binding to normal non-epithelial cells typical for healthy subjects with inflammation, trauma, surgical intervention or benign epithelial disease $(53,54)$.
These results are particularly dangerous in evaluating the tumour response after therapy. Yet, in general, immunocytological techniques are a method of choice for detection of micrometastases in bone marrow $(52,55,56)$.

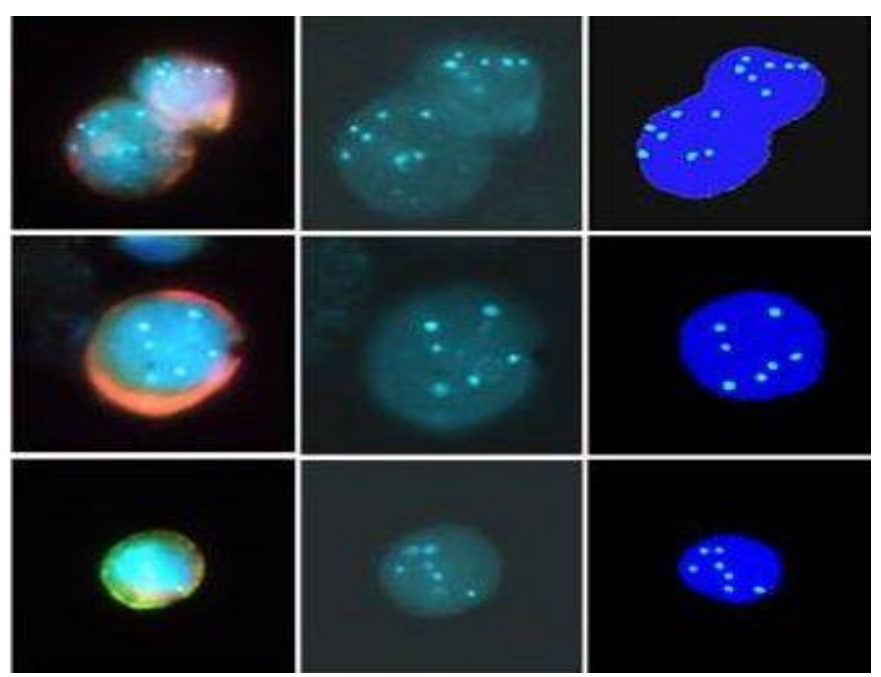

Figure 4. Circulating tumour cells isolated by peripheral blood filtration in colorectal cancer patients /Jian-Mei Hou et al, American Journal of Pathology. 2009;175:808-816)

Despite the flaws, immunocytochemistry has the advantage to preserved cell morphology and permits the identification of different groups of cells. It permits a simultaneous assessment of other cell traits as proliferative activity and oncogene expression $(57,58)$.

\section{Molecular biology techniques}

Polymerase chain reaction (PCR) and reverse transcription polymerase chain reaction (RTPCR)

PCR is introduced in 1990. At present, it is the most commonly used technique for CTC detectin $(59,60)$.

The specificity of the method is based on the possibility to find out specific DNA or mRNA regions by their amplification with specific oligonucleotide primers flanking these sequences.

DNA is more stable than RNA and thus, more suitable for investigation. Freely circulating DNA fragments could be detected in blood, for example consequently to release from nonviable tumour cells, hence the risk of false positive results. It was found out that only a few chromosome abberations are frequent and sensitive enough for identification of CTC.
That is why, modern techniques are focused on CTC detection by proving and determining the mRNA of specific tumour or tissue-specific genes by RT-PCR. After isolation of total RNA from blood, a complementary DNA is first synthesized by reverse transcriptase, also called copy DNA. It is further used as a matrix for amplification of a pair of specific primers, limiting gene sequence that is to be determined, evidencing an expression of this gene (Figure 5). The number of mRNA copies for a given gene could vary during the cell life cycle and yield a false positive result. This limitation is avoided by using two approaches for gene selection in RT-PCR reaction (61).

The first is based on detection of tumour-specific anomalies occurring in $\mathrm{s}$ given gene region by either PCR or RT-PCR. The second approach uses detection of the expression of tissuespecific markers on the surface of tumour cells by RT-PCR. Now, this method is considered as the most sensitive for detection of CTC (1 tumour cell per 1-10 million normal cells, approximately 1 tumour cell per $1-10 \mathrm{~mL}$ blood) $(20,61,62,63)$. The advantage of the method is its high specificity (Table 2). Its high efficiency is due to the possibility to analyze the entire genomic DNA or RNA in one run. There are 
however some limitations. A disadvantage of the method is the impossibility to perform a further analysis of tumour cells. As a paradox, its high sensitivity is also a drawback. An erroneous transcription (low level of gene transcription in all cells), contamination of the sample (64) or the presence of pseudogenes (genes without intron sequences) could yield false positive results after the PCR amplification. Other causes for erroneous results are markers with low specificity (65) or potential spread of
PETROV A., et al. normal/benign cells after invasive procedure (64). On the contrary, variability in PCR sensitivity could result in false negative results. Possible causes for such variability could be: a) circulating tumour cells do not express equally the studied marker; b) presence of PCR inhibitors in tissues and body fluids reducing the sensitivity of the reaction; в) damage of the target gene by performed therapy $(8,42,66,67$, $68)$.

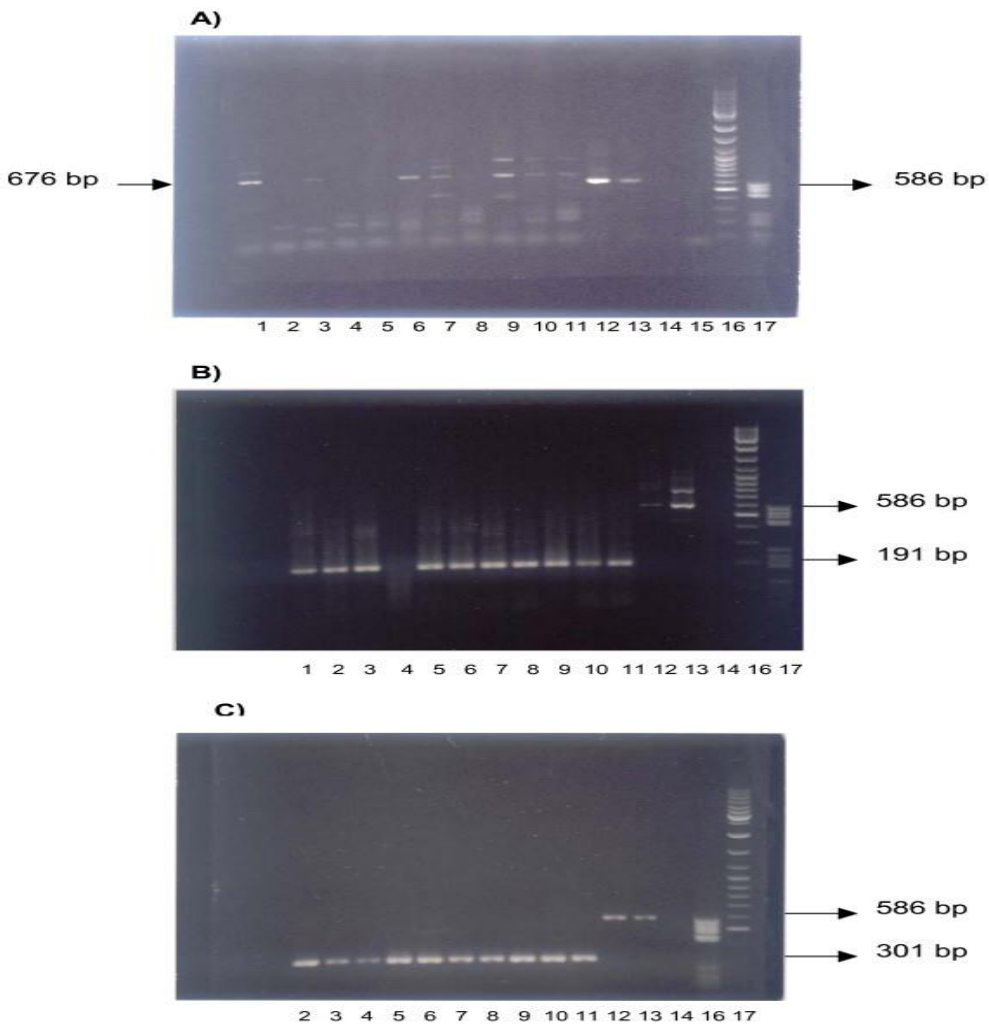

Figure 5. RT-PCR amplification products: A), PRSS22, B) RANBP3 and C) TMEM69 gene expression. Gene's lanes are marked as followed: 1-4 - blood RNA from healthy subjects, 5-RNA from normal leukocytes, 6 - blood from colorectal cancer patients, 7- RNA from normal colonic mucosa, 8- RNA from colon adenocarcinoma patient, 9 -normal mucosa from control subjects , 10-11 - disease-free mucosa and colon cancer from the same patient, 12-13 - PCR-positive controls, 14-15 - negative controls, 16-17 - 1 $\mu \mathrm{L}$ molecular markers: MBI V and GeneRuler (Genenco), respectively (Bertolini et al., Nat. Rev. Cancer 2006; 6(11): 835-845)

The analysis of causes for false positive and false negative results in RT-PCR method shows that it is not easy to be automated. Although, it permits to distinguish tumour cells from normal cells, an exact quantitation of CTC in the sample is not possible. The aforementioned disadvantages of the methods could be overcome by a correct and consecutive combination between them $(68,69,70$, and 71$)$.

The most commonly used markers for CTC detection in colorectal cancer by RT-PCR are CK-19, CK-20, K-PAH, MUC and guanylin cyclase (Figure 6) $(72,73,74,75,76)$. 


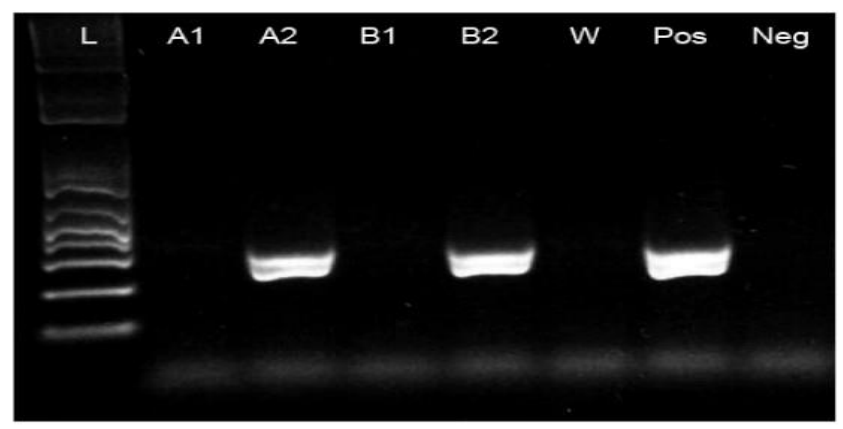

Figure 6. RT-PCR amplification products for mRNA of cytokeratin-20 after immunomagnetic enrichment with Ep-Cam antibodies (Antolovic et al., BMC Biotechnology 2010; 10:35)

Table 2. Sensitivity and specificity of PCR and RT-PCR.

\begin{tabular}{|c|c|c|c|c|c|}
\hline Year & Author & Method & $\begin{array}{c}\text { Number of } \\
\text { patients }\end{array}$ & Sensitivity & Specificity \\
\hline \multirow[t]{3}{*}{2004} & \multirow[t]{3}{*}{ R. SCHUSTER } & proTM & \multirow[t]{3}{*}{129} & $17 \%$ & $\mathrm{P}=0.12$ \\
\hline & & CEA & & $86 \%$ & $\mathrm{P}=0.055$ \\
\hline & & СК20 & & $88.4 \%$ & $\mathrm{P}=0.018$ \\
\hline $2005 \Gamma$. & Zhang XW & CK20 & 58 & $69,0 \%$ & $\mathrm{P}<0.01$ \\
\hline \multirow[t]{3}{*}{2006} & \multirow[t]{3}{*}{ Wang JY } & CK-19 & \multirow[t]{3}{*}{72} & $66.7 \%$ & \multirow[t]{3}{*}{$\mathrm{P}=0.006$} \\
\hline & & CK-20 & & $52.8 \%$ & \\
\hline & & CEA & & $72.2 \%$ & \\
\hline 2008 & $\underline{\text { Yie SM }}$ & $\begin{array}{c}\text { RT-PCR } \\
\text { ELISA }\end{array}$ & 86 & $44 \%$ & $\mathrm{P}<0.001$ \\
\hline \multirow[t]{3}{*}{2010 г. } & \multirow[t]{3}{*}{ Tsouma A } & CEA & \multirow{3}{*}{88} & $84 / 95.5 \%$, & \multirow[t]{3}{*}{$\mathrm{P}<0.001$} \\
\hline & & CK20 & & $69 / 78.4 \%$ & \\
\hline & & $\begin{array}{l}\text { EGFR } \\
\end{array}$ & & $17 / 19.3 \%$ & \\
\hline 2010 & Vogelaar FJ & CK-ICC & 46 & $33 \%$ & $\mathrm{p}=0.002$ \\
\hline
\end{tabular}

\section{CellSearch system}

Recently, the FDA approved a system for detection of circulating tumour cells in peripheral blood. It is an automated immunomagnetic method for tumour cells detection (Figures 7 and 8) $(77,78)$.

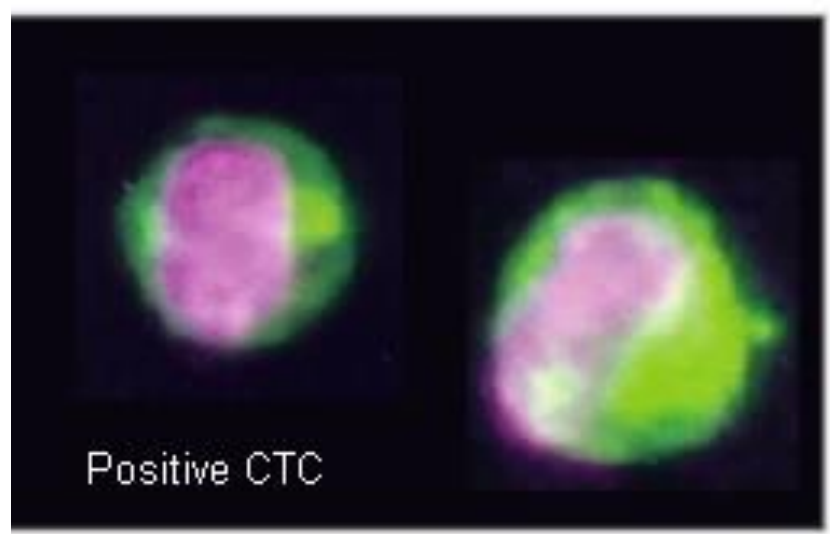

Figure 7. Visualization of positive CTC by the CellSearch system (CD45-, EpCAM+, and cytokeratins 8, 18+, and /or 19+) in blood (CTC (Circulating Tumor Cell Detection) Assay is available at the UCLA Biomarker Innovations Laboratory) 


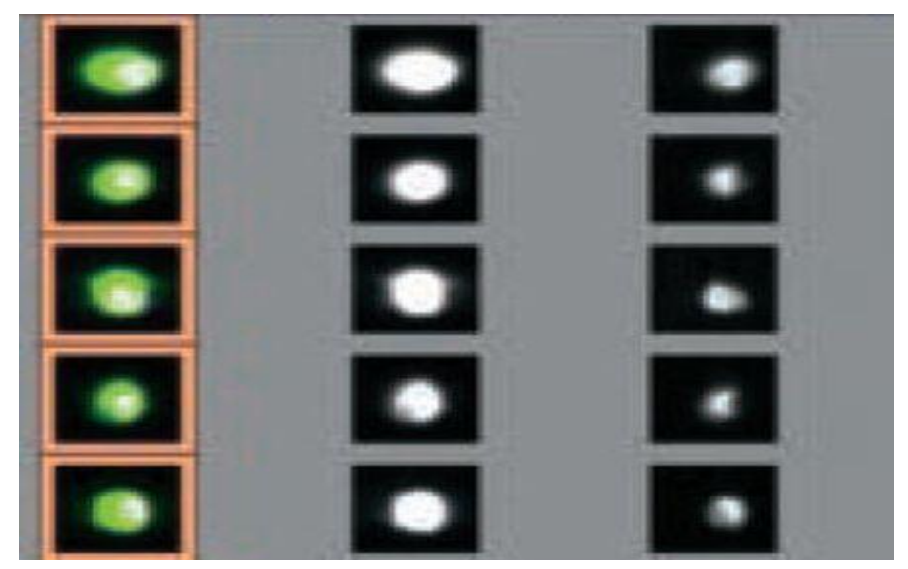

PETROV A., et al.

Figure 8. Visualization of circulating tumour cells (CK-PE +, DAPI +, CD45-APC-), as seen on a CellSearch analyzer (The CellSearch Assay for Circulating Tumor Cells: An Advance in Cancer Prognosis and Treatment, Copyright (C) 1995- 2011 Mayo Foundation for Medical Education and Research)

This system was utilized by Miller et al. 2010, which found out that the amount of tumour cells in the blood of colorectal cancer patients correlated with disease stage, but not with other morphological parameters $\mathrm{P}=0.005$ (Table 3) $(79,80,81)$.

Table 3 Sensitivity and specificity of CellSearch system.

\begin{tabular}{|c|c|c|c|c|}
\hline Year & Author & $\begin{array}{c}\text { Number of } \\
\text { patients }\end{array}$ & Sensitivity & Specificity \\
\hline 2008 & J. Sastre & 94 & $36,2 \%$ & $\mathrm{P}=0.005$ \\
\hline 2010 & Miller MC & 413 & $38 \%$ & $\mathrm{P}<0.001$ \\
\hline 2010 & Yalcin S & 130 & $32 \%$ & $\mathrm{p}=0.001$ \\
\hline
\end{tabular}

\section{DISCUSSION}

The detection of circulating tumour cells is essential from both theoretical and practical points of view. It allows obtaining in vivo information about the metastatic process, and in the future, additional information about the interaction between the tumour and immune system could be anticipated. This would add to our knowledge on the mechanism of tumour growth and could help the development of new drugs and therapeutic protocols $(82,83,84)$.

Metastases occur secondary to the interaction between tumour cells and patient's cells. During their movement in peripheral blood, many tumour cells are killed by immune response, but the metastatic potential of remaining ones could not be underestimated or excluded. The occurrence of tumour cells in systemic circulation entails tumour relapse. That is why, the early detection of these cells followed by their immediate eradication by cytostatic drugs or perhaps following individual cytostatic treatment protocol could prevent the development of metastases $(58,85)$.

The ability of tumour cells to migrate is a part of their metastatic potential (86), and methods developed for their detection in blood circulation resulted in reassessment of the risk for relapse and provided new therapeutic possibilities (87). It was proved that minimal residual disease in bone marrow, peritoneal punctate or in lymph nodes correlates to poorer prognosis and shorter survival period $(88,89,90)$.

Papavasiliou et al. established a significant correlation between post operative presence of CTC, the progression of disease and the overall survival rate. In their belief, from a clinical point of view, the post operative detection of tumour cells in peripheral blood could be the most suitable indicator for occult clinical disease (91). Vardakis et al. provided evidence for considerable lower disease-free survival (DFS) 
( $\mathrm{P}<0,001)$, and overall survival $(\mathrm{P}=0.017)$ in patients with circulating tumour cells detected by RT-PCR. These data show that CTC are an independent prognostic factor for reduction of DFS (92).

Rahbari et al. performed a meta-analysis showing a bad prognosis on the basis of blood CTC detection in colorectal cancer patients (93). In cancer treatment, the search for and the detection of minimal residual disease has the following important functions: to determined the efficacy of performed therapy, to compare the different therapeutic protocols, to monitor patients at risk for progression of the disease and last but not least, to identify patients needing more aggressive therapy $(77,94,95)$.

At present, the treatment of colorectal cancer patients (Dukes A and B, TNM stages I and II) is operative (96). After diagnosing a progression (Dukes C and D, TNM stages III and IV) adjuvant chemotherapy is indicated apart surgery $(97,98,99)$.

Nevertheless, the result from the treatment is rather variable and therefore, the prognostication of therapeutic response on the basis of conventional criteria is not consistent $(96,99$, 100).

The detection of the amount of peripheral blood CTC could be useful for the consequent monitoring of cytostatic drug efficacy and the related therapeutic effect $(101,102)$.

According to Hampton et al., detected tumour cells are markers of therapy's efficiency, including for patients treated surgically in an early stage of disease (103).

The detection and quantitation of tumour cells in peripheral blood could be a unique method for diagnostics, prognostication and therapeutic efficacy evaluation.

That is why, a considerable interest is raised for development of more stable and more predictable disease markers $(104,105)$.

Markers based on circulating CEA and various levels of tumour-associated gene mutations, including microsatellite instability, loss of heterozygocity of the $18 \mathrm{p}$ and DCC genes, and
PETROV A., et al. mutations in K-RAS, B-RAF and PIK3CA genes are with proved prognostic value $(44,79,104$, 106).

In particular, mutations in K-RAS, B-RAF and PIK3CA genes were recently advanced as reliable marker to predict the response to EGFR targeted immunotherapy $(107,108)$.

\section{CONCLUSION}

The appearance of tumour cells in peripheral blood is an early sign of metastasis. Despite the systemic mechanisms of defense, single cancer cells could be detected in remote areas under the form of colonies as an initial stage for formation of a distal metastasis (109)

As forerunner of a secondary relapse, circulating tumour cells detected after radical surgery could be used for prediction and monitoring of disease, being independent prognostic factors of the further progression of the neoplasm $(75,81$, 110).

They could broaden the therapy options both with approved drugs and by using epithelially targeted monoclonal antibodies. A highly sensitive method for prognosis of the metastatic potential and clinical results is needed for undertaking a proper treatment. These markers could provide prognostic information independently from and in addition to traditional tumour markers $(111,112)$.

In conclusion, circulating tumour cells possess a considerable metastatic potential and their eradication influences directly the survival of patients. This way, the improvement of methods for early diagnostics and the subsequent specific characterization of initial tumour levels have caused a revision of concepts for operative and conservative treatment of cancer patients. Future research would provide new alternatives for individual assessment of risk for metastasis, different from the standard and commonly accepted TNM staging.

\section{REFERENCES}

1. Parkin DM, Stjernswörd J, Muir CS. Estimates of the worldwide frequency of twelve major cancers. Bull WHO 62: 163$182 ; 1984$

2. GLOBOCAN 2008, Cancer Incidence and Mortality Worldwide in 2008, 2008 
3. Weitz J, Koch M, Debus J, Höhler T, Galle PR, Büchler MW: Colorectal cancer. Lancet, 365:153-165; 2005.

4. Jemal A, Siegel R, Ward E, Murray T, Xu J, Thun MJ. Cancer Statistics, 2007. CA Cancer J. Clin. 57, 43-66, 2007.

5. SEER Cancer Statistics Review, 1975-2003. National Cancer Institute, retrieved; 2006 [http://seer.cancer.gov/csr/1975-2003/]

6. August DA, Ottow RT, Sugarbaker PH Clinical perspective of human colorectal cancer matastasis. Cancer Metatsasis Rev 3:303-324, 1984

7. Tebbutt NC, Cattell E, Midgley R, Cunningham D, Kerr D Systemic treatment of colorectal cancer. Eur J Cancer 38:10001015, 2002.

8. Ghossein RA, Bhattacharya S. Molecular detection and characterisation of circulating tumour cells and micrometastases in solid tumours. Eur J Cancer 36:1681-94, 2000

9. Nelson NJ. Circulating tumor cells: will they be clinically useful? J Natl Cancer Inst. 2010 Feb 3;102(3):146-8, 2010

10. Keene SA, Demeure MJ The clinical significantce of micrometastases and molocular metastases. Surgery;20;10271034, 2001

11. Braun S, Naume B:Circulating and disseminated tumor cells. J Clin Oncol 23; 1623-1626, 2005

12. Hermanek $P$ et al Clasiffication of isolated tumor cells and micrometastases. Cancer, 86;2668-2673, 1999

13. Fielding LP, Henson DE Miltiple prognostic factors and outcome analysis in patients with cancer. Commonication from the American Join Communities on Cancer. Cancer;712426-2429, 1993

14. Sharp JG, Kessinger A et al: Detection and clinical significance of minimal tumor cells contamination in peripheral stem cells harvest. Int j Cell Cloning; 10; (Supp;1); 92, 1992

15. Stadmauer EA, Tsai DE et al: Stem cells transplantation for metastatic breast cancer: analysis of tumor contamination. Med Oncol 16; 279-288, 1999

16. Rao B, Han M, Wang L, Gao X, Huang J, Huang M, Liu H, Wang J. Clinical outcomes of active specific immunotherapy in advanced colorectal cancer and suspected
PETROV A., et al. minimal residual colorectal cancer: a metaanalysis and system review. J Transl Med. 9(1):17, 2011

17. Skrovina M, Duda M, Srovnal J, Bartos J, Radová L, Hajdúch $M$, Soumarová R. Detection of minimal residual disease and its significance for establishing prognoses in patients with laparoscopic resections of colorectal carcinomas. Rozhl Chir. Jul;89(6):362-9, 2010

18. Xi-Wei Zhang, Hong-Yu Yang, Ping Fan, Li Yang, Guo-Yu Chen, Detection of micrometastasis in peripheral blood by multi-sampling in patients with colorectal cancer, World J Gastroenterol;11(3):436438, 2005

19. Coman DR, deLong RP, MccUtcheon M. Studies on the mechanisms of metastasis; the distribution of tumors in various organs in relation to the distribution of arterial emboli. Cancer Res. 11(8), 648-651, 1951.

20. Mocellin S, Keilholz U, Rossi CR, Nitti D. Circulating tumor cells: the 'leukemic phase' of solid cancers. Trends Mol. Med. 12(3), 130-139, 2006

21. Swartz MA, Krotonson CA, Melder RJ et al; cells shed from tumors show reduced clonogenicity, resistance to apoptosis and in vivo tumorogenicity. BrJ Cancer 81; 756959; 1999

22. Kerr D: Clinical development of gene therapy бfor colorectal cancer. Nat Rev Cancer, 3:615-622, 2003

23. Weiss L. Metastasis of cancer: a conceptual history from antiquity to the 1990s. Cancer Metastasis Rev. 19(3-4), 193-383, 2000

24. Liefers GJ, Cleton-Jansen AM, van de Velde CJ, Hermans J, van Krieken JH, Cornelisse CJ, Tollenaar RA: Micrometastases and survival in stage II colorectal cancer. N Engl J Med, 339:223228, 1998.

25. Rahbari NN, Reissfelder C, Mühlbayer M, Weidmann K, Kahlert C, Büchler MW, Weitz J, Koch M. Correlation of Circulating Angiogenic Factors with Circulating Tumor Cells and Disease Recurrence in Patients Undergoing Curative Resection for Colorectal Liver Metastases. Ann Surg Oncol. 18 (8) :2182-91, 2011

26. Liu F, Yu J, Liang YZ, Hu YF, Wang YN, Li GX. Associated risk factors of peritoneal 
metastasis in colorectal cancer. Zhonghua Wei Chang Wai Ke Za Zhi. 14(4):254-6, 2011

27. Sato H, Maeda K, Sugihara K, Mochizuki $\mathrm{H}$, Kotake K, Teramoto T, Kameoka S, Saito Y, Takahashi K, Hirai T, Ohue M, Shirouzu K, Sakai Y, Watanabe T, Hirata K, Hatakeyama K.High-risk stage II colon cancer after curative resection. J Surg Oncol. doi: 10.1002/jso.21914, 2011

28. Karina Kl, Wyckoff JB et al; Cells motility of tumor cells visualized in living intact primary tumor using green fluorescent protein. Cancer res; 58; 2528-2532, 1998

29. Sckell A, Safabakhsh N et al: Primary tumor size-dependent inhibition of angiogenesis at a secondary site: an intravital microscopic study in mice. Cancer Res; 58; 5866-5869, 1998

30. Sloane JP, Ormerod MG. Distribution of epithelial membrane antigen in normal and neoplastic tissues and its diagnostic tumor pathology. Cancer; 47; 1786-1795, 1981

31. Gazzaniga P, Gradilone A, Petracca A, Nicolazzo C, Raimondi C, Iacovelli R, Naso $\mathrm{G}$, Cortesi E. Molecular markers in circulating tumour cells from metastatic colorectal cancer patients. J Cell Mol Med.;14(8):2073-7, 2010

32. Lindemann F, Schlimok G, Dirschedl P, Witte $\mathrm{J}$ and Riethmuller G. Prognostic significance of micrometastatic tumour cells in bone marrow of colorectal cancer patients. Lancet340, $685 \pm 689,1992$

33. Schott A, Vogel I, Krueger U, Kalthoff H, Schreiber HW, Schmiegel W, Henne-Bruns $\mathrm{D}$, Kremer B and Juhl $\mathrm{H}$. Isolated tumor cells are frequently detectable in the peritoneal cavity of gastric and colorectal cancer patients and serve as a new prognostic marker. Ann. Surg. 227, $372 \pm$ 379, 1998

34. O'Brien CA, Pollett A, Gallinger S, Dick JE: A human colon cancer cell capable of initiating tumour growth in immunodeficient mice. Nature, 445:106110, 2007

35. S. Riethdorf, H. Wikman, K. Pantel, Review: biological relevance of disseminated tumor cells in cancer patients, Int. J. Cancer 123 1991-2006, 2008
PETROV A., et al.

36. Riedell $\mathrm{B}$, Landis $\mathrm{K}$; Incidence and histopathology in biopsies of metastases of mammary carcinoma in biopsies from the posterior iliac crest. Cancer;1782-1788, 1979

37. Thomas J Moss:Minimal residual cancer detection in hematopoetic stem cell product and its prognostic significance in patients with breast camcer,lymphoma or multiple mieloma; Cancer Cont J;5; Vol 5; 2000

38. Salsbury AJ. The significance of the circulating cancer cell. Cancer Treat Rev 2:55-72, 1975

39. Leather AJ, Gallegos NC, Kocjan G, Savage F, Smales CS, Hu W, Boulos PB, Northover IM, and Philips RK: Detection and enumeration of circulating tumor cells in colorectal cancer. Lr J Surg, 80:777-780, 1993

40. Griffiths JD, McKinna JA, Rowbotham HD, Tsolakidis P, Salsbury AJ: Carcinoma of the colon and rectum: circulating malignant cells and five-year survival. Cancer, 31:226-236, 1973

41. Hirsch-Ginsberg C; Detection of minimal residual disease: relevance for diagnosis and treatment of human malignancies. Anu rev Med;49;111-122, 1998

42. Johnson PW, Burchill et al: The molecular detection of circulating tumor cells. $\mathrm{Br} J$ Cancer;72;268-276, 1995

43. Klein CA: The biology and analysis of single disseminated tumor cells. Trends Cell Biol; 10; 489-493, 2000.

44. Allen JE, El-Deiry WS. Circulating Tumor Cells and Colorectal Cancer. Curr Colorectal Cancer Rep. 1;6(4):212-220, 2010

45. He W, Wang H, Hartmann LC, Cheng JX, Low PS. In vivo quantitation of rare circulating tumor cells by multiphoton intravital flow cytometry. Proc Natl Acad Sci U S A. 10;104(28):11760-5. 2007.

46. Ntouroupi TG, Ashraf SQ, McGregor SB, Turney BW, Seppo A, Kim Y, Wang X, Kilpatrick MW, Tsipouras $P$, Tafas $T$, Bodmer WF.Detection of circulating tumour cells in peripheral blood with an automated scanning fluorescence microscope. Br J Cancer. 2;99(5):789-95, 2008. 
47. Hwu D, Boutrus S, Greiner C, Dimeo T, Kuperwasser C, Georgakoudi I. Assessment of the role of circulating breast cancer cells in tumor formation and metastatic potential using in vivo flow cytometry. $J$ Biomed Opt.;16(4):040501, 2011.

48. LR Gauthier, C Granotier, J-C Soria, S Faivre, V Boige, E Raymond and FD Boussin. Detection of circulating carcinoma cells by telomerase Activity British Journal of Cancer 84(5), 631-635, 2001

49. Koelink PJ, Lamers CB, Hommes DW, Verspaget HW. Circulating cell death products predict clinical outcome of colorectal cancer patients. BMC Cancer. 23;9:88, 2009.

50. Schlimok G, Funke I, Holzmann B, Gottlinger G, Schmidt G, Hauser H. et al. Micrometastatic cancer cells in bone marrow: in vitro detection with anticytokeratin and in vivo labeling with anti17-iA monoclonal antibodies. Proc NatI Acad Sci U S A:84: 8672-6, 1987

51. Cutait R, Alves VAF, Lopes LC, Cutait DE, Borges ILA, Singer I, et al. Restaging of colorectal cancer based on the identification of lymph node micrometastases through immunoperoxidase staining of CEA and cytokeratins. Dis Colon Rectum:34:917-20, 1991

52. Racila E, Euhus D, Weiss AJ, Rao C, McConnell J, Terstappen LW, Uhr JWDetection and characterization of carcinoma cells in the blood. Proc Natl Acad Sci USA 95: 4589-4594, 1998

53. Goeminne JC, Guillaume T. Detection of circulating tumor by reverse transcriptase polymerase chain reaction. J. Clin. Oncol. 18(17), 3196-3197, 2000.

54. Silva JM, Rodriguez R, Garcia JM et al. Detection of epithelial tumour RNA in the plasma of colon cancer patients is associated with advanced stages and circulating tumour cells. Gut 50(4), 530 534, 2002.

55. Ntouroupi T, Seppo A, Wang S, Kim Y, Tsipouras P, Tafas T, Kilpatrick MW, Bodmer WF Robotic microscopy for detection and analysis of circulating tumor cells. Presented at the annual meeting of The American Society of Human Genetics, October 2007, San Diego, California, 2007
PETROV A., et al.

56. Song J, From P, Morrissey WJ, Sams J Circulating cancer cells: pre- and postchemotherapy observations. Cancer 28: 553-561, 1971

57. Tsavellas G, Patel H, Alen-Mersh TG: Detection of circulating significance of occult tumor cells in colorectal cancer. $\mathrm{Br} \mathrm{J}$ Surg, 88:1307-1320, 2001

58. Negin BP, Cohen SJ.Circulating tumor cells in colorectal cancer: past, present, and future challenges. Curr Treat Options Oncol. ;11(1-2):1-13, 2010.

59. Altman DG. Practical statistics for Medical Research. London: Chapman and Hall; 1991.

60. Boom R, Sol CJ, Salimans MM, Jansen CL, Wertheim-van Dillen PM, van der Noordaa J. Rapid and simple method for purification of nucleic acids. J Clin Microbiol.;28:495503, 1990

61. Bertolini F, Shaked Y, Mancuso P, Kerbel RS. The multifaceted circulating endothelial cell in cancer: towards marker and target identification. Nat. Rev. Cancer 6(11), 835845, 2006.

62. Gerhard $M$, Juhl $H$, Kalthoff $H$ et al. Specific detection of carcinoembryonic antigen-expressing tumor cells in bone marrow aspirates by polymerase chain reaction. J. Clin. Oncol. 12(4), 725-729, 1994.

63. Yie SM, Lou B, Ye SR, Cao M, He X, Li P, $\mathrm{Hu}$ K, Rao L, Wu SM, Xiao HB, Gao E. Detection of survivin-expressing circulating cancer cells (CCCs) in peripheral blood of patients with gastric and colorectal cancer reveals high risks of relapse. Ann Surg Oncol.;15(11):3073-82, 2008

64. Kaplan JC, Kahn A, Chelly J. Illegitimate transcription: its use in the study of inherited disease. Hum. Mutat. 1(5), 357360, 1992.

65. Schoenfeld A, Luqmani Y, Smith D et al. Detection of breast cancer micrometastases in axillary lymph nodes by using polymerase chain reaction. Cancer Res. 54(11), 2986-2990, 1994.

66. Ghossein RA, Carusone L, Bhattacharya S. Review: polymerase chain reaction detection of micrometastases and circulating tumor cells: application to melanoma, 
prostate, and thyroid carcinomas. Diagn. Mol. Pathol. 8(4), 165-175, 1999.

67. Tsouma A, Aggeli C, Lembessis P, Zografos GN, Korkolis DP, Pectasides D, Skondra M, Pissimissis N, Tzonou A, Koutsilieris M. Multiplex RT-PCR-based detections of CEA, CK20 and EGFR in colorectal cancer patients. World $J$ Gastroenterol. 21;16(47):5965-74, 2010

68. Tsouma A, Aggeli C, Pissimissis N, Lembessis P, Zografos GN, Koutsilieris M. Circulating tumor cells in colorectal cancer: detection methods and clinical significance. Anticancer Res.;28(6B):3945-60, 2008

69. Smerage JB, Hayes DF. The measurement and therapeutic implications of circulating tumour cells in breast cancer. Br. J. Cancer 94(1), 8-12, 2006.

70. Hu XC, Wang Y, Shi DR, Loo TY, Chow LW. Immunomagnetic tumor cell enrichment is promising in detecting circulating breast cancer cells. Oncology 64(2), 160-165, 2003

71. Vogelaar FJ, Mesker WE, Rijken AM, van Pelt GW, van Leeuwen AM, Tanke HJ, Tollenaar RA, Liefers GJ. Clinical impact of different detection methods for disseminated tumor cells in bone marrow of patients undergoing surgical resection of colorectal liver metastases: a prospective follow-up study. BMC Cancer. 20;10:153, 2010

72. Bustin S. A., Gyselman V. G., Williams N. S., Dorud i S. Detection of cytokeratins $19 / 20$ and guanylyl cyclase in peripheral blood of colorectal cancer patients. Br. J. Cancer, 79: 1813-1820, 1999

73. Burchill S. A., Bradbury M. F., Pittman K., Southgate J., Smith B., Selby P. Detection of epithelial cancer cells in peripheral blood by reverse transcriptase-polymerase chain reaction. Br. J. Cancer., 71: 278-281, 1995

74. Schuster R, Max N, Mann B, Heufelder K, Thilo F, Gröne J, Rokos F, Buhr HJ, Thiel E, Keilholz U.Quantitative real-time RTPCR for detection of disseminated tumor cells in peripheral blood of patients with colorectal cancer using different mRNA markers. Int J Cancer. 10;108(2):219-27, 2004

75. G Peach, C Kim, E Zacharakis, S Purkayastha and P Ziprin, Prognostic
PETROV A., et al. significance of circulating tumour cells following surgical resection of colorectal cancers: a systematic review, British Journal of Cancer 102, 1327-1334, 2010

76. Yang MJ, Chiu HH, Wang HM, Yen LC, Tsao DA, Hsiao CP, Chen YF, Wang JY, Lin SR. Enhancing detection of circulating tumor cells with activating KRAS oncogene in patients with colorectal cancer by weighted chemiluminescent membrane array method. Ann Surg Oncol.;17(2):62433, 2010

77. Cohen SJ, Alpaugh RK, Gross $\mathrm{S}$ et al. Isolation and characterization of circulating tumor cells in patients with metastatic colorectal cancer. Clin Colorectal Cancer; 6: 125-132, 2006

78. Moreno JG, Miller MC, Gross $\mathrm{S}$ et al. Circulating tumor cells predict survival in patients with metastatic prostate cancer. Urology 65: 713-718, 2005

79. Miller MC, Doyle GV, Terstappen LW. Significance of Circulating Tumor Cells Detected by the CellSearch System in Patients with Metastatic Breast Colorectal and Prostate Cancer. J Oncol. 2010:617421, 2010

80. Sastre J, Maestro ML, Puente J, Veganzones S, Alfonso R, Rafael S, GarcíaSaenz JA, Vidaurreta M, Martín M, Arroyo M, Sanz-Casla MT, Díaz-Rubio E Circulating tumor cells in colorectal cancer: correlation with clinical and pathological variables. Ann Oncol.;19(5):935-8, 2008

81. Yalcin S, Kilickap S, Portakal O, Arslan C, Hascelik G, Kutluk T.Determination of circulating tumor cells for detection of colorectal cancer progression or recurrence. Hepatogastroenterology.;57(104):1395-8, 2010

82. Bela Molnar, Andras Ladanyi, Lenke Tanko, et al. Circulating Tumor Cell Clusters in the Peripheral Blood of Colorectal Cancer Patients, Clin Cancer Res;7:4080-4085, 2001

83. Xenidis N, Ignatiadis M, Apostolaki S, Perraki M, Kalbakis K, Agelaki S, et al. Cytokeratin-19 mRNA-positive circulating tumor cells after adjuvant chemotherapy in patients with early breast cancer. J Clin Oncol;27:2177-84, 2009 
84. Meropol NJThe significance of circulating tumor cells as prognostic markers for colon cancer. Clin Adv Hematol Oncol.;7(4):2478, 2009

85. Hodgson DR, Wellings R, Orr MC, McCormack R, Malone M, Board RE, Cantarini MV.Circulating tumour-derived predictive biomarkers in oncology. Drug Discov Today.;15(3-4):98-101, 2010

86. Mocellin S, Keilholz U, Rossi CR, Nitti D. Circulating tumor cells: the 'leukemic phase' of solid cancers. Trends Mol. Med. 12(3), 130-139, 2006

87. Takeuchi H, Kitagawa Y.Circulating tumor cells in gastrointestinal cancer. $J$ Hepatobiliary Pancreat Sci.;17(5):577-82, 2010

88. J.J. Gaforio, M.J. Serrano, P. SanchezRovira, A. Sirvent, M. Delgado- Rodriguez, M. Campos, N. de la Torre, I. Algarra, R. Duenas, A. Lozano, Detection of breast cancer cells in the peripheral blood is positively correlated with estrogen-receptor status and predicts for poor prognosis, Int. J. Cancer 107 984-990, 2003

89. S.J. Cohen, C.J. Punt, N. Iannotti, B.H. Saidman, K.D. Sabbath, N.Y. Gabrail, J. Picus, M. Morse, E. Mitchell, M.C. Miller, G.V. Doyle, H. Tissing, L.W. Terstappen, N.J. Meropol, Relationship of circulating tumor cells to tumor response, progressionfree survival, and overall survival in patients with metastatic colorectal cancer, $J$. Clin. Oncol. 26 3213-3221, 2008

90. J. Tol, M. Koopman, M.C. Miller, A. Tibbe, A. Cats, G.J. Creemers, A.H. Vos, I.D. Nagtegaal, L.W. Terstappen, C.J. Punt, Circulating tumour cells early predict progression-free and overall survival in advanced colorectal cancer patients treated with chemotherapy and targeted agents, Ann. Oncol., 2009.

91. Papavasiliou P, Fisher T, Kuhn J, Nemunaitis J, Lamont J.Circulating tumor cells in patients undergoing surgery for hepatic metastases from colorectal cancer. Proc (Bayl Univ Med Cent). 23(1):11-4, 2010

92. Nikolaos Vardakis, Ippokratis Messaritakis, Chara Papadaki, Georgios Agoglossakis, Maria Sfakianaki, Zacharenia Saridaki, Stella Apostolaki, Ioannis Koutroubakis,
PETROV A., et al. Maria Perraki, Dora Hatzidaki, Dimitris Mavroudis, Vassilis Georgoulias, and John Souglakos, Prognostic Significance of the Detection of Peripheral Blood CEACAM5mRNA-Positive Cells by Real Time Polymerase Chain Reaction in Operable Colorectal Cancer, Clin Cancer Res;17:165-173, 2011.

93. Rahbari NN, Aigner M, Thorlund K, Mollberg N, Motschall E, Jensen K, Diener MK, Büchler MW, Koch M, Weitz J. Metaanalysis shows that detection of circulating tumor cells indicates poor prognosis in patients with colorectal cancer. Gastroenterology.;138(5):1714-26, 2010

94. Simkens LH, Tol J, Terstappen LW, Teerenstra S, Punt CJ, Nagtegaal ID. The predictive and prognostic value of circulating endothelial cells in advanced colorectal cancer patients receiving first-line chemotherapy and bevacizumab. Ann Oncol. 21(12):2447-8, 2010

95. Garrigós N, Gallego J, Guillén-Ponce C, Guaraz P, García-Bautista M, Castillejo A, Gómez-Martínez A, Carrato A, RodríguezLescure A, Soto JL.Circulating tumour cell analysis as an early marker for relapse in stage II and III colorectal cancer patients: a pilot study. Clin Transl Oncol.;12(2):142-7, 2010

96. Hind R, Rew DR, Johnson CD: Surgical excision alone is adequate for treatment for primary colorectal cancer. Annals of the Royal College of Surgeons of England 74:63-67, 1992

97. Andre T, Boni C, Mounedji-Boudiaf J, Navarro M, Tabernero J, Topham C, Zaninelli M, Clingan P, Bridgewater J, Tabah-Fisch I, Gramont A: Oxaliplatin, fluorouracil and leucovorin as adjuvant treatment for colon cancer. New England Journal of Medicine, 350:2343-2351, 2004

98. Goldberg RM, Rothenberg ML, Can Cutsem E, Benson AB, Blanke CD, Diasio RB, Grothey A, Ramanathan RK, Wickham $\mathrm{R}$, Armstrong D, Viele C: The continuum of care: a paradigm for the management of metastatic colorectal cancer. Oncologist, 12:38-50, 2007

99. Doillard JY, Bennouna J: Adjuvant chemotherapy for colon cancer: a confusing 
arena! Annals of Oncology, 16:1853-1854, 2005

100. Compton CC, Greene FL: The staging of colorectal cancer: 2004 and beyond. $C A$ Cancer J Clin, 54:295-308, 2004

101. Aimery de Gramont, Joleen Hubbard, Qian Shi, Michael J. O'Connell, Marc Buyse, Jacqueline Benedetti, Brian Bot, Chris O'Callaghan, Greg Yothers, Richard M. Goldberg, Charles D. Blanke, Al Benson, Qiqi Deng, Steven R. Alberts, Thierry Andre, Norman Wolmark, Axel Grothey, and Daniel Sargent Association Between Disease-Free Survival and Overall Survival When Survival Is Prolonged After Recurrence in Patients Receiving Cytotoxic Adjuvant Therapy for Colon Cancer: Simulations Based on the 20,800 Patient ACCENT Data Set, J Clin Oncol 28:460465, 2009

102. Cohen SJ, Punt CJ, Iannotti N, Saidman BH, Sabbath KD, Gabrail NY, Picus J, Morse MA, Mitchell E, Miller MC, Doyle GV, Tissing H, Terstappen LW, Meropol NJ Prognostic significance of circulating tumor cells in patients with metastatic colorectal cancer. Ann Oncol:;20(7):1223-9, 2009

103. Regina Hampton, Mignon Walker, John Marshall and Hartmut Juhl, Differential expression of carcinoembryonic antigen (CEA) splice variants in whole blood of colon cancer patients and healthy volunteers: implication for the detection of circulating colon cancer cells, Oncogene 21, $7817-7823,2002$

104. Walther A, Johnstone E, Swanton C, Midgley R, Tomlinson I, Kerr D: Genetic prognostic and predictive markers in colorectal cancer. Nat Rev Cancer, 7:489499, 2009

105. Duffy MJ, Van Dalen A, Haglund C, Hansson L, Holinski-Feder E, Klapdor R, Peltomaki P, Sturgeon C, Topolcan O: Tumour markers in colorectal cancer: European Group on Tumour Markers (EGTM) guidelines for clinical use. Eur $J$ Cancer, 43:1348-1360, 2007
106. Shankaran V, Wisinski KB, Mulcahy MF, Benson AB: The role of molecular markers in predicting response to therapy in patients with colorectal cancer. Mol Diag Ther, 12:87-98, 2008

107. Philips J, Wang R, Marwah S, Silver M, Tzardi M, Silver J, Ogino S, Hooshmand S, Kwak E, Freed E, Meyerhardt JA, Saridaki Z, Georgoulias V, Finkelstein D, Fuchs CS, Kulke MH, Shivdasani RA: Common mutations linked to adverse colorectal cancer outcomes. Br J Cancer, 101:465472, 2009

108. Sartore-Bianchi A, Di Nicolantonio F, Nichelatti M, Molinari F, De Dosso S, Saletti P, Martini M, Cipani T, Marrapese G, Mazzucchelli L, Lamba S, \ Veronese S, Frattini M, Bardelli A, Siena S: Multideterminants analysis of molecular alterations for predicting clinical benefit to EGFR-targeted monoclonal antibodies in colorectal cancer. PLoS One, 4:e7287, 2009

109. Iinuma $\mathrm{H}$, Watanabe $\mathrm{T}$, Mimori $\mathrm{K}$, Adachi M, Hayashi N, Tamura J, Matsuda K, Fukushima R, Okinaga K, Sasako M, Mori M. Clinical significance of circulating tumor cells, including cancer stem-like cells, in peripheral blood for recurrence and prognosis in patients with dukes' stage B and C colorectal cancer. J Clin Oncol. 20;29(12):1547-55, 2011

110. de Bono JS, Attard G, Adjei A, et al: Potential applications for circulating tumor cells expressing he insulin-like growth factor-I receptor. Clin Cancer Res 13:36113616, 2007

111. Rosenberg R, Hoos A, Mueller J, Nekarda H. Impact of cytokeratin-20 and carcinoembryonic antigen mRNA detection by RT-PCR in regional lymph nodes of patients with colorectal cancer. $\mathrm{Br} \quad J$ Cancer; 83: 1323-1329, 2000

112. Funke I, Schraut W. Meta-analyses of studies on bone marrow micrometastases: An independent prognostic impact remains to be substantiated. J Clin Oncol; 16: 557566, 1998 